\title{
Catalytic Behavior of Crosslinked Polystyrene Bound Platinum Complex in Hydrosilylation of Olefins
}

\author{
Chengyou KAN, ${ }^{\dagger}$ Xiangzheng Kong,${ }^{*}$ Chimin DU, ${ }^{*}$ and Deshan LiU \\ Department of Chemical Engineering, School of Materials Science and Engineering, Tsinghua University, \\ Beijing 100084, P. R. China \\ *Department of Chemistry, Shandong University, Jinan 250100, P. R. China
}

(Received September 12, 2000; Accepted November 3, 2001)

\begin{abstract}
A thiolmethylated crosslinked polystyrene bound platinum complex was prepared and used to catalyze the hydrosilylation of olefins with dichloromethyl silane (DCMS) and diethoxymethyl silane (DEMS). This complex was an active catalyst for the hydrosilylation of styrene and alkyl acrylates, but had no catalytic activity for the hydrosilylation of olefins containing two substituents on a double bond. When used as the catalyst for the addition of DCMS to allyl methacrylate, only 3-methacryloyloxypropyl dichloromethylsilane was obtained. This complex thus catalyzes the hydrosilylation of 1-dodecene or allyl chloride with DCMS, whereas the addition of DEMS to the two olefins would not take place under the same conditions. This catalyst could be used 18 times without appreciable active loss in the hydrosilylation of styrene with DCMS.
\end{abstract}

KEY WORDS Polymer Bound Platinum Complex / Catalytic Behavior / Hydrosilylation / Olefins

/ Dichloromethyl Silane / Diethoxylmethyl Silane /

Hydrosilylation is one of the most important reactions in organosilicon chemistry and organic synthesis, and many silicones containing special functional groups have been synthesized via this reaction. Since the homogeneous chloroplatinic acid solution (Speier's catalyst) is a good catalyst for the hydrosilylation of olefins and acetylenes in 1950's, ${ }^{1,2}$ solutions of platinum complexes with various ligand groups are considered the most effective catalysts and are widely used in many applications. ${ }^{3-7}$ Recently, K. Kishi et al. ${ }^{8,9}$ reported a new homogeneous thermal latent hydrosilylation catalysts on the basis of chloroplatinic acid and polystyrene derivatives containing propargyl or isocyanide groups, and the "too high" activity of common platinum catalysts in crosslinking reaction of organosilicon resin was improved effectively by these catalysts. However, use of homogeneous catalysts on an industrial scale leads to a number of practical problems, including recovery of the catalyst from the reaction products, and deposition of the catalyst on the surface of a reactor. To overcome these problems, several heterogeneous hydrosilylation catalysts of polymer bound transition metal complexes have been synthesized in the past two decades.

These heterogeneous catalysts are often prepared by attaching a transition metal compound to a macromolecular bearing electron-donating ligand groups, and two supports concerning organic polystyrene and inorganic silica were, respectively, reported by Capka and Allum et al. ${ }^{10,11}$ for the first time. Since the catalytic behavior of the complexes may be greatly affected by changes of ligand groups, electronic and steric effects, it is desirable to prepare polymer bound catalysts containing new ligand groups, and new hydrosilylation catalysts have been synthesized. ${ }^{12-19}$

A thiol-containing compound easily forms a complex with chloroplatinic acid. ${ }^{20,21}$ In the previous work, ${ }^{22,23}$ thiolmethylated styrene-divinyl benzene copolymer supported platinum complex (xPSt-SH-Pt) was prepared and used to catalyze the hydrosilylation of alkynes and trialkyl vinyl silanes with dichloromethyl silane (DCMS), and high catalytic activity was observed. The hydrosilylation of acetylene could not stop at one-step addition, and saturated product was obtained, but only one-step addition occurred for phenyl acetylene. In this work, the structure of this complex was determined, and its catalytic behavior for the hydrosilylation of a great variety of olefins with DCMS and diethoxymethyl silane (DEMS) was studied.

\section{EXPERIMENTAL}

\section{Materials}

Microporous gel type chloromethylated poly(styrene-divinyl benzene) $\left(\mathrm{xPSt}-\mathrm{CH}_{2} \mathrm{Cl}\right)$ with a $7 \% \mathrm{~mol}$ of divinyl benzene and $13.2 \%$ weight of chlorine were supplied by Qilu Petrochemical Company. Microbead diameter was $1-2 \mathrm{~mm}$, and density was $1.04 \mathrm{~g} \mathrm{~cm}^{-3}$. Chloroplatinic acid and thiourea were of analytical grade and used without further treatment. Solvents (in-

†To whom all correspondence should be addressed (Tel: +86-10-62773456, E-mail: kancy@tsinghua.edu.cn). 


$$
\begin{aligned}
& \stackrel{\mathrm{S}}{\|} \underset{\mathrm{xPSt}-\mathrm{CH}_{2} \mathrm{C} 1+\mathrm{H}_{2} \mathrm{NCNH}_{2} \stackrel{\mathrm{DMSO} / \text { toluene }}{\longrightarrow} \mathrm{xPSt}-\mathrm{CH}_{2} \mathrm{SCNH}_{2} \cdot \mathrm{HCl}}{\|} \\
& \stackrel{\mathrm{NH}_{3}}{\longrightarrow} \mathrm{xPSt}-\mathrm{CH}_{2} \mathrm{SH}(\mathrm{xPSt}-\mathrm{SH})
\end{aligned}
$$

Scheme 1. Preparation of xPSt-SH polymer ligand.

cluding dimethyl sulphoxide, toluene and ethanol) were analytical reagents and dried with molecular sieves before use. DCMS was purchased from Beijing 2th petrochemical factory. DEMS was prepared by the reported procedure. ${ }^{24}$ Styrene, 1-dodecene, cyclohexene, allyl chloride, methyl acrylate, butyl acrylate, methyl methacrylate, butyl methacrylate and allyl methacrylate were analytical reagents and purified by distillation under normal or reduced pressure before use.

\section{Preparation and Characterization of xPSt-SH-Pt Complex}

Yellow colored microbeads of xPSt-SH-Pt complex were synthesized by the reported method as follows: ${ }^{22,23}$ A polymer ligand of thiolmethylated poly(styrene-divinyl benzene) (xPSt-SH) was first prepared via nucleophilic substitution at the chloromethyl groups with thiourea and followed by ammonolysis in a mixture of DMSO and toluene (Scheme 1). The xPSt-SH-Pt complex was obtained through reaction of xPSt-SH with $\mathrm{H}_{2} \mathrm{PtCl}_{6}$ in ethanol. The composition and structure of the complex were determined by infred spectra (IR-50DX), elemental analysis (Perkin-Elmer 240C) and X-Ray photoelectron spectroscopy (XPS, PHI5300ESCA/610SAM).

\section{Hydrosilylation}

Hydrosilylation was conducted in a three-necked flask equipped with a mechanical stirrer, reflux condenser and thermometer. The ingredients were controlled at an olefin/ $\mathrm{Pt}$ mol ratio of 1400 and $\mathrm{Si}-\mathrm{H} /$ olefin mol ratio of 1.3. As a comparative experiment, a $0.06 \mathrm{M}$ solution of chloroplatinic acid in isopropyl alcohol $\left(\mathrm{H}_{2} \mathrm{PtCl}_{6} / i\right.$-PrOH $)$ was used to catalyze the same hydrosilylations under the same conditions. $0.1 \mathrm{~g}$ xPStSH-Pt catalyst, $65 \mathrm{mmol}$ of hydrosilylation reagent (DCMS or DEMS) and $50 \mathrm{mmol}$ of olefin were used in a typical run. The temperature in the reactor in the whole reaction process was controlled so that the reaction medium would be slightly refluxed. Reflux temperature rose gradually with addition reaction, and hydrosilylation was considered complete when no reflux was observed in the reflux condenser. For hydrosilylation of all olefins here reported with DCMS and DEMS, final temperatures in the reactor were about $70^{\circ} \mathrm{C}$ and
Table I. Results of XPS analysis

\begin{tabular}{lccc}
\hline \multirow{2}{*}{ Compound } & \multicolumn{3}{c}{ Binding energy/eV } \\
\cline { 2 - 4 } & $\mathrm{Pt}(4 \mathrm{f})$ & $\mathrm{S}(2 \mathrm{p})$ & $\mathrm{C} 1(2 \mathrm{p})$ \\
\hline xPSt-SH-Pt & 73.3 & 164.2 & 199 \\
xPSt-SH & & 163.4 & \\
Chloroplatinic acid & 75.3 & & 199.1 \\
\hline
\end{tabular}

$110^{\circ} \mathrm{C}$.

\section{Characterization}

Yields of hydrosilylation products based on the olefins were determined on a Shanghai 101 GC instrument equipped with a TCD detector $(10 \%$ SE-30 on 101 support, gradient temperature of 80 to $250^{\circ} \mathrm{C}$,

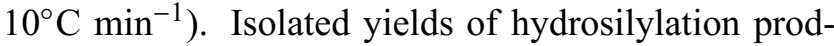
ucts were obtained by distillation first at atmospheric pressure, followed by fractional distillation under reduced pressure on a high efficiency distillation equipment (Perkin-Elmer). ${ }^{1} \mathrm{H}$ NMR spectra of the separated products were recorded on a nuclear magnetic resonance instrument (XF-90Q) with $\mathrm{CDCl}_{3}$ as solvent. Product structure was deduced from proton shifts and the corresponding integral curve on the spectra.

\section{Catalyst Reusability}

A reuse test of the catalyst was made in the hydrosilylation of styrene with DCMS. For each cycle of the test, the reaction vessel was first cooled to room temperature, and the solution was decanted completely, leaving the catalyst microbeads on the bottom of the reactor. The same amounts of the reactants were recharged, and the next cycle started.

\section{RESULTS AND DISCUSSIONS}

\section{Composition and Structure of the xPSt-SH-Pt Catalyst}

In the IR spectrum of xPSt-SH, two absorption peaks of $v_{\mathrm{C}-\mathrm{S}}\left(\mathrm{m}, 699 \mathrm{~cm}^{-1}\right)$ and $v_{\mathrm{S}-\mathrm{H}}\left(\mathrm{w}, 2595 \mathrm{~cm}^{-1}\right)$ were observed, and no $v_{\mathrm{C}-\mathrm{Cl}}$ absorption appeared at $671 \mathrm{~cm}^{-1}$. Elemental analysis showed that this complex contained $11.6 \%$ sulfur by weight. Nearly all of the chloromethyl groups linked to crosslinked polystyrene are thus replaced by thiolmethyl groups. A $3.82 \mathrm{~mol} \mathrm{ra}-$ tio of S/Pt in xPSt-SH-Pt complex was determined by XPS.

XPS data of the xPSt-SH-Pt complex, xPSt-SH and chloroplatinic acid are shown in Table I. The binding energy of $\mathrm{Pt}(4 \mathrm{f})$ in the xPSt-SH-Pt complex is $73.3 \mathrm{eV}$, which is $2.0 \mathrm{eV}$ less than that in chloroplatinic acid $(75.3 \mathrm{eV})$, whereas $\mathrm{Cl}(2 \mathrm{p})$ binding energy is similar to that of chloroplatinic acid. The decrease of $\mathrm{Pt}(4 \mathrm{f})$ binding energy in the catalyst means increase in electron density. The $\mathrm{S}(2 \mathrm{p})$ binding energy of the $\mathrm{xPSt}-\mathrm{SH}-\mathrm{Pt}$ 
Table II. Hydrosilylation of olefins with DCMS

\begin{tabular}{|c|c|c|c|c|c|}
\hline \multirow[b]{2}{*}{ Olefin } & \multirow[b]{2}{*}{ Product $^{\mathrm{a}}$} & \multicolumn{2}{|c|}{ XPSt-SH-Pt } & \multicolumn{2}{|c|}{$\mathrm{H}_{2} \mathrm{PtCl}_{6} / i-\mathrm{PrOH}$} \\
\hline & & $\frac{\text { Reaction time }}{\min }$ & Yield $\mathrm{b} / \%$ & $\frac{\text { Reaction time }}{\min }$ & Yield/\% \\
\hline \multirow{2}{*}{ Styrene } & $\mathrm{PhCH}_{2} \mathrm{CH}_{2} \mathbf{R}(\mathrm{C} 1)$ & \multirow{2}{*}{70} & $79(72)$ & \multirow{2}{*}{180} & 66.3 \\
\hline & $\mathrm{Ph}\left(\mathrm{CH}_{3}\right) \mathrm{CHR}(\mathrm{C} 2)$ & & $21(19)$ & & 21 \\
\hline 1-Dodecene & $\mathrm{CH}_{3}\left(\mathrm{CH}_{2}\right)_{9} \mathrm{CH}_{2} \mathrm{CH}_{2} \mathbf{R}(\mathrm{C} 3)$ & 80 & $63(53)$ & 330 & 79 \\
\hline Allyl chloride & $\mathrm{ClCH}_{2} \mathrm{CH}_{2} \mathrm{CH}_{2} \mathbf{R}(\mathrm{C} 4)$ & 30 & $54(51)$ & 420 & 52.6 \\
\hline Cycolhexene & Cyclo- $\mathrm{C}_{6} \mathrm{H}_{11} \mathbf{R}(\mathrm{C} 5)$ & 600 & 0 & 600 & 69 \\
\hline \multirow{2}{*}{ Methyl acrylate } & $\mathrm{CH}_{3} \mathrm{OOCCH}\left(\mathrm{CH}_{3}\right) \mathbf{R}(\mathrm{C} 6)$ & \multirow{2}{*}{110} & $57.8(52)$ & \multirow{2}{*}{360} & 51 \\
\hline & $\mathrm{CH}_{3} \mathrm{OOCCH}_{2} \mathrm{CH}_{2} \mathbf{R}(\mathrm{C} 7)$ & & $10.3(9)$ & & 8.5 \\
\hline \multirow{2}{*}{ Butyl acrylate } & $\mathrm{C}_{4} \mathrm{H}_{9} \mathrm{OOCCH}\left(\mathrm{CH}_{3}\right) \mathbf{R}(\mathrm{C} 8)$ & \multirow{2}{*}{102} & $55.8(52)$ & \multirow{2}{*}{360} & 49 \\
\hline & $\mathrm{C}_{4} \mathrm{H}_{9} \mathrm{OOCCH}_{2} \mathrm{CH}_{2} \mathbf{R}(\mathrm{C} 9)$ & & $17.1(14)$ & & 11 \\
\hline $\begin{array}{l}\text { Methyl } \\
\text { methacrylate }\end{array}$ & $\begin{array}{l}\mathrm{CH}_{3} \mathrm{OOCCH}\left(\mathrm{CH}_{3}\right) \mathrm{CH}_{2} \mathbf{R} \\
(\mathrm{C} 10)\end{array}$ & 600 & 0 & 180 & 64 \\
\hline $\begin{array}{l}\text { Butyl } \\
\text { methacrylate }\end{array}$ & $\begin{array}{l}\mathrm{C}_{4} \mathrm{H}_{9} \mathrm{OOCCH}\left(\mathrm{CH}_{3}\right) \mathrm{CH}_{2} \mathbf{R} \\
(\mathrm{C} 11)\end{array}$ & 600 & 0 & 180 & 42.4 \\
\hline $\begin{array}{l}\text { Allyl } \\
\text { methacrylate }\end{array}$ & $\begin{array}{l}\mathrm{CH}_{2}=\mathrm{CMeCOOCH}_{2} \mathrm{CH}_{2} \mathrm{CH}_{2} \mathbf{R} \\
\text { (C12) }\end{array}$ & 55 & $99.8(90)$ & 150 & 77.2 \\
\hline
\end{tabular}

$$
\begin{aligned}
& \mathrm{RCH}=\mathrm{CH}_{2}+\mathrm{H}-\mathrm{Si} \equiv \rightarrow \mathrm{RCH}_{2} \mathrm{CH}_{2} \mathrm{Si} \equiv+\mathrm{RCHCH}_{3} \\
& \mathrm{Si} \equiv \\
& \text { ( } \beta \text {-product } \quad(\alpha \text {-product) }
\end{aligned}
$$

Scheme 2. Hydrosilylation of alkene.

is $0.8 \mathrm{eV}$ more than that of xPSt-SH. The increase of $\mathrm{S}(2 \mathrm{p})$ binding energy in the catalyst implies decrease in electron density. These results may be taken as evidence of $\mathrm{S} \rightarrow \mathrm{Pt}$ coordination bond in the $\mathrm{xPSt}-\mathrm{SH}-\mathrm{Pt}$ complex.

\section{Hydrosilylation of Olefins with DCMS}

The hydrosilylation of olefins is shown in Scheme 2. Alpha- and $\beta$-addition products may be obtained for terminal alkenes. Reaction activity and structure of products may be determined by steric and electronic effects of the reactants, as well as stereospecific effects of the catalyst.

Reaction time and product yield in the hydrosilylation of various olefins with DCMS catalyzed by the xPSt-SH-Pt and $\mathrm{H}_{2} \mathrm{PtCl}_{6} / i-\mathrm{PrOH}$ are summarized in Table II. Structures of the products were confirmed by ${ }^{1} \mathrm{H}$ NMR, and the results are given in Table III. xPSt$\mathrm{SH}-\mathrm{Pt}$ was much more effective for styrene than for others. High yield was reached within 70 min with $\beta$ addition product as the main product. This is attributed to the conjugated effect of phenyl group and steric effects in the reactants. In the alkyl acrylate hydrosilylation, since $\mathrm{Si}$ atoms are more electrophilic than $\mathrm{H}$ atoms in the $\mathrm{Si}-\mathrm{H}$ bonds, and carboxyl in the alkyl acrylates is electrophilic, the main products are dominated by polarity effects of the reactants. Thus more $\alpha$-product was obtained than $\beta$-product.

For hydrosilylation of allyl chloride and 1-dodecene with DCMS, only $\beta$-product was obtained. The low yield (54\%) of allyl chloride hydrosilylation was due to exchange of $\mathrm{Cl}$ atom in allyl chloride with $\mathrm{H}$ atom in DCMS. ${ }^{25}$

The xPSt-SH-Pt complex could not catalyze hydrosilylation of cyclohexene with DCMS. As above noted in the previous work, ${ }^{22}$ when this complex was employed to catalyze the hydrosilylation of phenyl acetylene with DCMS, only one-step addition product was obtained in spite of the amount of DCMS. That is, the addition of 1-phenyl-2-dichloromethylsilyl ethylene with DCMS could not be catalyzed by the xPSt$\mathrm{SH}-\mathrm{Pt}$ complex. The steric hindrance of $\mathrm{C}=\mathrm{C}$ bonds in 1,2-di-substituted olefins would be the reason.

xPSt-SH-Pt did not show catalytic activity in the hydrosilylation of alkyl methacrylates with DCMS. But $\mathrm{Pt} / \mathrm{C}$ (platinum on charcoal) ${ }^{26}$ and $\mathrm{SiO}_{2}$-bound platinum complex ${ }^{15}$ catalyze methyl methacrylates with DCMS, and yields of $58 \%$ and $79 \%$ of $\beta$-product were noted. The addition just took place on $\mathrm{C}=\mathrm{C}$ bonds in allyl group with high yield of $\beta$-product (99.8\%) in the hydrosilylation of allyl methacrylate with DCMS. This special selectivity is very important and useful for the preparation of methacryloyloxypropyl-functional organosilicons widely used as coupling agents and starting materials. ${ }^{27}$ 
Table III. ${ }^{1}$ H NMR data of products for the hydrosilylation of olefins with DCMS

\begin{tabular}{|c|c|}
\hline Product & ${ }^{1} \mathrm{H} \mathrm{NMR} / \delta$, ppm \\
\hline $\mathrm{C} 1$ & $\begin{array}{l}0.6-0.76\left(3 \mathrm{H}, \mathrm{CH}_{3}-\mathrm{Si}\right), 1.4-1.6\left(2 \mathrm{H},-\mathrm{CH}_{2}-\mathrm{Si}\right), 2.62-2.88\left(2 \mathrm{H},-\mathrm{CH}_{2}-\mathrm{Ph}\right) \\
7.24(5 \mathrm{H},-\mathrm{Ph})\end{array}$ \\
\hline $\mathrm{C} 2$ & $0.6-0.76\left(3 \mathrm{H}, \mathrm{CH}_{3}-\mathrm{Si}\right), 1.48\left(3 \mathrm{H}, \mathrm{CH}_{3}-\mathrm{C}\right), 2.76(1 \mathrm{H},-\mathrm{CH}-), 7.24(5 \mathrm{H},-\mathrm{Ph})$ \\
\hline $\mathrm{C} 3$ & $0.72\left(3 \mathrm{H}, \mathrm{CH}_{3}-\mathrm{Si}\right), 0.85\left(3 \mathrm{H}, \mathrm{CH}_{3}-\mathrm{C}\right), 1.12-1.32\left(22 \mathrm{H},-\mathrm{CH}_{2}-\right)$ \\
\hline $\mathrm{C} 4$ & $0.72\left(3 \mathrm{H}, \mathrm{CH}_{3}-\mathrm{Si}\right), 1.21-1.64\left(4 \mathrm{H},-\mathrm{CH}_{2}-\right), 3.21\left(2 \mathrm{H}, \mathrm{Cl}-\mathrm{CH}_{2}-\right)$ \\
\hline $\mathrm{C} 5$ & $0.71\left(3 \mathrm{H}, \mathrm{CH}_{3}-\mathrm{Si}\right), 1.22-1.98\left(11 \mathrm{H}, \mathrm{C}_{6} \mathrm{H}_{11}-\mathrm{Si}\right)$ \\
\hline C6 & $0.82\left(3 \mathrm{H}, \mathrm{CH}_{3}-\mathrm{Si}\right), 1.28\left(3 \mathrm{H}, \mathrm{CH}_{3}-\mathrm{C}\right), 2.48(1 \mathrm{H},-\mathrm{CH}-), 4.06\left(3 \mathrm{H}, \mathrm{CH}_{3}-\mathrm{O}\right)$ \\
\hline $\mathrm{C} 7$ & $0.84\left(3 \mathrm{H}, \mathrm{CH}_{3}-\mathrm{Si}\right), 1.25\left(2 \mathrm{H},-\mathrm{CH}_{2}-\mathrm{Si}\right), 2.14\left(2 \mathrm{H},-\mathrm{CH}_{2}-\right), 4.05\left(3 \mathrm{H}, \mathrm{CH}_{3}-\mathrm{O}\right)$ \\
\hline $\mathrm{C} 8$ & $\begin{array}{l}0.78-0.98\left(6 \mathrm{H}, \mathrm{CH}_{3}-+\mathrm{CH}_{3}-\mathrm{Si}\right), 1.2-1.72\left(7 \mathrm{H}, \mathrm{CH}_{3}-\mathrm{C}+-\mathrm{CH}_{2}-\right) \\
2.44(1 \mathrm{H},-\mathrm{CH}-\mathrm{Si}), 4.08\left(2 \mathrm{H},-\mathrm{CH}_{2}-\mathrm{O}\right)\end{array}$ \\
\hline C9 & $\begin{array}{l}0.78-1.0\left(6 \mathrm{H}, \mathrm{CH}_{3}-\mathrm{Si}+\mathrm{CH}_{3}-\right), 1.24-1.68\left(6 \mathrm{H},-\mathrm{CH}_{2}-+-\mathrm{CH}_{2}-\mathrm{Si}\right) \\
2.14\left(2 \mathrm{H},-\mathrm{CH}_{2}-\mathrm{COO}\right), 4.09\left(2 \mathrm{H},-\mathrm{CH}_{2}-\mathrm{O}\right)\end{array}$ \\
\hline $\mathrm{C} 10$ & $\begin{array}{l}0.78-0.99\left(6 \mathrm{H}, \mathrm{CH}_{3}-\mathrm{C}+\mathrm{CH}_{3}-\mathrm{Si}\right), 1.4-1.52\left(2 \mathrm{H},-\mathrm{CH}_{2}-\mathrm{Si}\right) \\
2.18(1 \mathrm{H},-\mathrm{CH}-\mathrm{COO}), 4.06\left(3 \mathrm{H}, \mathrm{CH}_{3}-\mathrm{O}\right)\end{array}$ \\
\hline $\mathrm{C} 11$ & $\begin{array}{l}0.77-1.02\left(9 \mathrm{H}, \mathrm{CH}_{3}-+\mathrm{CH}_{3}-\mathrm{C}+\mathrm{CH}_{3}-\mathrm{Si}\right), 1.22-1.7\left(6 \mathrm{H},-\mathrm{CH}_{2}-\mathrm{Si}+-\mathrm{CH}_{2}-\right) \text {, } \\
2.2(1 \mathrm{H},-\mathrm{CH}-\mathrm{COO}), 4.1\left(2 \mathrm{H},-\mathrm{CH}_{2}-\mathrm{O}\right)\end{array}$ \\
\hline $\mathrm{C} 12$ & $\begin{array}{l}0.76\left(3 \mathrm{H}, \mathrm{CH}_{3}-\mathrm{Si}\right), 1.20\left(2 \mathrm{H},-\mathrm{CH}_{2}-\mathrm{Si}\right), 1.74-2.04\left(5 \mathrm{H},-\mathrm{CH}_{2}-+\mathrm{CH}_{3}-\mathrm{C}=\right) \\
4.14\left(2 \mathrm{H},-\mathrm{CH}_{2} \mathrm{O}\right), 5.14-6.4\left(2 \mathrm{H}, \mathrm{H}_{2} \mathrm{C}=\right)\end{array}$ \\
\hline
\end{tabular}

To compare the behavior of this heterogeneous catalyst with that of a common homogeneous catalyst, $\mathrm{H}_{2} \mathrm{PtCl}_{6} / i$-PrOH was used to catalyze the hydrosilylation of olefins with DCMS (see Table II). Thus (a) the xPSt-SH-Pt complex has higher catalytic activity than the $\mathrm{H}_{2} \mathrm{PtCl}_{6} / i$-PrOH for styrene, alkyl acrylates, and allyl methacrylate. (b) $\mathrm{H}_{2} \mathrm{PtCl}_{6} / i$-PrOH catalyze the hydrosilylation of cyclohexene and alkyl methacrylates though relative low yields were obtained, but xPSt$\mathrm{SH}-\mathrm{Pt}$ has no any activity toward these olefins even if reaction time is extended to $600 \mathrm{~min}$. This specific behavior of the xPSt-SH-Pt is certainly related to special polymeric effects. Further study is in progress at this laboratory.

\section{Hydrosilylation of Olefins with DEMS}

The hydrosilylation results of various olefins with DEMS and the ${ }^{1} \mathrm{H}$ NMR spectra data are shown in Table IV and V. Similar results were obtained for DEMS and DCMS. The xPSt-SH-Pt complex had higher catalytic activity than the $\mathrm{H}_{2} \mathrm{PtCl}_{6} / i$-PrOH for olefins with one conjugated substituent (styrene and alkyl acrylates), but there was no activity for olefins with two substituents on $\mathrm{C}=\mathrm{C}$ bond (cyclohexene and alkyl methacrylates). By comparing Table IV with Table II, the xPSt-SH-Pt complex did not catalyze the hydrosilylation of 1-dodecene, allyl chloride or allyl methacrylate with DEMS though catalytic activity was observed in the hydrosilylation of these olefins with DCMS. These differences are due to the different activities of hydrosilylation reagents. In general, hydrosilylation activity is determined by the activity of the olefin and hydrosilylation reagent when the catalyst is given.

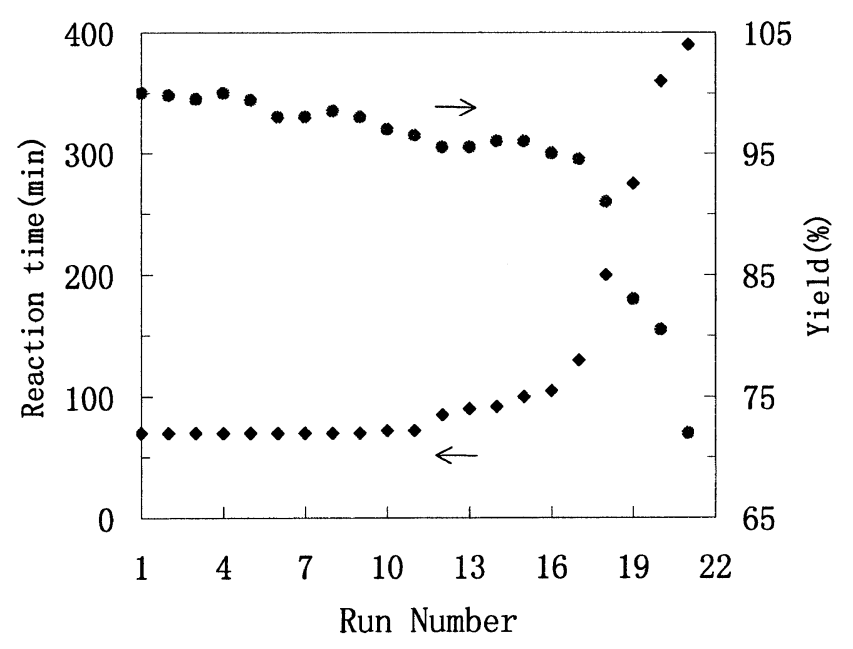

Figure 1. Reaction time $(\bullet)$ and total yield $(\bullet)$ for hydrosilylation of styrene with DCMS.

The activity of hydrosilylation reagents is closely connected to electron cloud density on $\mathrm{Si}-\mathrm{H}$ bonds. The less the electron cloud density of $\mathrm{Si}-\mathrm{H}$ bond, the higher is the activity of hydrosilylation reagent. ${ }^{28}$ The electron cloud density on $\mathrm{Si}-\mathrm{H}$ bond in DCMS is much less than that in DEMS because of the presence of two $\mathrm{Cl}$ atoms in DCMS. The activity of DEMS is thus much less than that of DCMS.

\section{Reuse of Catalyst}

The hydrosilylation of St with DCMS was done an example to test the reusability of this catalyst. Results are given in Figure 1. Catalytic activity of xPSt-SHPt complex remained nearly unchanged in the first 9 reuse, and more than $98 \%$ of total yields of products was reached within $70 \mathrm{~min}$. With increase of reuse time from 9 to 17 , reaction time gradually increased 
Table IV. Hydrosilylation of olefins with DEMS

\begin{tabular}{|c|c|c|c|c|c|}
\hline \multirow[b]{2}{*}{ Olefin } & \multirow[b]{2}{*}{ Product $^{\mathrm{a}}$} & \multicolumn{2}{|c|}{ XPSt-SH-Pt } & \multicolumn{2}{|c|}{$\mathrm{H}_{2} \mathrm{PtCl}_{6} / i-\mathrm{PrOH}$} \\
\hline & & $\frac{\text { Reaction time }}{\min }$ & Yield $\mathrm{b} / \%$ & $\frac{\text { Reaction time }}{\min }$ & Yield/\% \\
\hline \multirow{2}{*}{ Styrene } & $\mathrm{PhCH}_{2} \mathrm{CH}_{2} \mathbf{R}^{\prime}(\mathrm{M} 1)$ & \multirow{2}{*}{65} & $73(65)$ & \multirow{2}{*}{180} & 64 \\
\hline & $\mathrm{Ph}\left(\mathrm{CH}_{3}\right) \mathrm{CHR}^{\prime}(\mathrm{M} 2)$ & & $27(24)$ & & 19 \\
\hline 1-Dodecene & $\mathrm{CH}_{3}\left(\mathrm{CH}_{2}\right)_{9} \mathrm{CH}_{2} \mathrm{CH}_{2} \mathbf{R}^{\prime}$ (M3) & 600 & 0 & 210 & 78 \\
\hline Allyl chloride & $\mathrm{ClCH}_{2} \mathrm{CH}_{2} \mathrm{CH}_{2} \mathbf{R}^{\prime}(\mathrm{M} 4)$ & 600 & 0 & 480 & 42 \\
\hline Cycolhexene & Cyclo- $\mathrm{C}_{6} \mathrm{H}_{11} \mathbf{R}^{\prime}(\mathrm{M} 5)$ & 600 & 0 & 600 & 18 \\
\hline \multirow{2}{*}{ Methyl acrylate } & $\mathrm{CH}_{3} \mathrm{OOCCH}\left(\mathrm{CH}_{3}\right) \mathbf{R}^{\prime}(\mathrm{M} 6)$ & \multirow{2}{*}{80} & $74(66)$ & \multirow{2}{*}{480} & 54 \\
\hline & $\mathrm{CH}_{3} \mathrm{OOCCH}_{2} \mathrm{CH}_{2} \mathbf{R}^{\prime}(\mathrm{M} 7)$ & & $24.8(22)$ & & 17 \\
\hline \multirow{2}{*}{ Butyl acrylate } & $\mathrm{C}_{4} \mathrm{H}_{9} \mathrm{OOCCH}\left(\mathrm{CH}_{3}\right) \mathbf{R}^{\prime}(\mathrm{M} 8)$ & \multirow{2}{*}{55} & $83(73)$ & \multirow{2}{*}{480} & 61 \\
\hline & $\mathrm{C}_{4} \mathrm{H}_{9} \mathrm{OOCCH}_{2} \mathrm{CH}_{2} \mathbf{R}^{\prime}(\mathrm{M} 9)$ & & $0.5(0)$ & & 4.2 \\
\hline $\begin{array}{l}\text { Methyl } \\
\text { methacrylate }\end{array}$ & $\begin{array}{l}\mathrm{CH}_{3} \mathrm{OOCCH}\left(\mathrm{CH}_{3}\right) \mathrm{CH}_{2} \mathbf{R}^{\prime} \\
\text { (M10) }\end{array}$ & 600 & 0 & 600 & 34 \\
\hline $\begin{array}{l}\text { Butyl } \\
\text { methacrylate }\end{array}$ & $\begin{array}{l}\mathrm{C}_{4} \mathrm{H}_{9} \mathrm{OOCCH}\left(\mathrm{CH}_{3}\right) \mathrm{CH}_{2} \mathbf{R}^{\prime} \\
\text { (M11) }\end{array}$ & 600 & 0 & 600 & 29 \\
\hline $\begin{array}{l}\text { Allyl } \\
\text { methacrylate }\end{array}$ & $\begin{array}{l}\mathrm{CH}_{2}=\mathrm{CMeCOOCH}_{2} \mathrm{CH}_{2} \mathrm{CH}_{2} \mathbf{R}^{\prime} \\
\text { (M12) }\end{array}$ & 600 & 0 & 480 & 82 \\
\hline
\end{tabular}

Table V. ${ }^{1} \mathrm{H}$ NMR data of products for the hydrosilylation of olefins with DEMS

\begin{tabular}{|c|c|}
\hline Product & ${ }^{1} \mathrm{H} \mathrm{NMR} / \delta, \mathrm{ppm}$ \\
\hline M1 & $\begin{array}{l}0.14\left(3 \mathrm{H}, \mathrm{CH}_{3}-\mathrm{Si}\right), 0.62-0.78\left(2 \mathrm{H},-\mathrm{CH}_{2}-\mathrm{Si}\right), 1.2\left(6 \mathrm{H}, \mathrm{CH}_{3}-\right), \\
2.54-2.68\left(2 \mathrm{H},-\mathrm{CH}_{2}-\mathrm{Ph}\right), 3.64-3.88\left(4 \mathrm{H},-\mathrm{CH}_{2}-\mathrm{O}\right), 7.22(5 \mathrm{H},-\mathrm{Ph})\end{array}$ \\
\hline M2 & $\begin{array}{l}0.14\left(3 \mathrm{H}, \mathrm{CH}_{3}-\mathrm{Si}\right), 1.2\left(6 \mathrm{H}, \mathrm{CH}_{3}-\right), 1.46\left(3 \mathrm{H}, \mathrm{CH}_{3}-\mathrm{C}\right), 2.74(1 \mathrm{H},-\mathrm{CH}-), \\
3.64-3.88\left(4 \mathrm{H},-\mathrm{CH}_{2}-\mathrm{O}\right), 7.24(5 \mathrm{H},-\mathrm{Ph})\end{array}$ \\
\hline M3 & $\begin{array}{l}0.13\left(3 \mathrm{H}, \mathrm{CH}_{3}-\mathrm{Si}\right), 0.68-0.85\left(5 \mathrm{H}, \mathrm{CH}_{3}-+-\mathrm{CH}_{2}-\mathrm{Si}\right) \\
1.1-1.32\left(26 \mathrm{H},-\mathrm{CH}_{2}-+\mathrm{CH}_{3}-\right), 3.62-3.87\left(4 \mathrm{H},-\mathrm{CH}_{2}-\mathrm{O}\right)\end{array}$ \\
\hline M4 & $\begin{array}{l}0.14\left(3 \mathrm{H}, \mathrm{CH}_{3}-\mathrm{Si}\right), 0.64-0.76\left(2 \mathrm{H},-\mathrm{CH}_{2}-\mathrm{Si}\right), 1.21-1.56\left(8 \mathrm{H},-\mathrm{CH}_{2}-+\mathrm{CH}_{3}-\right) \text {, } \\
3.2\left(2 \mathrm{H}, \mathrm{Cl}-\mathrm{CH}_{2}-\right), 3.63-3.8\left(4 \mathrm{H},-\mathrm{CH}_{2}-\mathrm{O}\right)\end{array}$ \\
\hline M5 & $0.14\left(3 \mathrm{H}, \mathrm{CH}_{3}-\mathrm{Si}\right), 0.98-1.96\left(17 \mathrm{H}, \mathrm{C}_{6} \mathrm{H}_{13}-\mathrm{Si}+\mathrm{CH}_{3}-\right), 3.62-3.86\left(4 \mathrm{H},-\mathrm{CH}_{2}-\mathrm{O}\right)$ \\
\hline M6 & $\begin{array}{l}0.16\left(3 \mathrm{H}, \mathrm{CH}_{3}-\mathrm{Si}\right), 1.1-1.65\left(10 \mathrm{H}, \mathrm{CH}_{3}-\mathrm{CH}-\mathrm{Si}+\mathrm{CH}_{3}-\right) \\
3.74-3.94\left(7 \mathrm{H},-\mathrm{CH}_{2}-\mathrm{O}+\mathrm{CH}_{3}-\mathrm{O}\right)\end{array}$ \\
\hline M7 & $\begin{array}{l}0.16\left(3 \mathrm{H}, \mathrm{CH}_{3}-\mathrm{Si}\right), 0.72\left(2 \mathrm{H},-\mathrm{CH}_{2}-\mathrm{Si}\right), 1.20\left(6 \mathrm{H}, \mathrm{CH}_{3}-\right), 2.02\left(2 \mathrm{H},-\mathrm{CH}_{2}-\mathrm{COO}\right), \\
3.48-3.96\left(7 \mathrm{H},-\mathrm{CH}_{2}-\mathrm{O}+\mathrm{CH}_{3}-\mathrm{O}\right)\end{array}$ \\
\hline M8 & $\begin{array}{l}0.15\left(3 \mathrm{H}, \mathrm{CH}_{3}-\mathrm{Si}\right), 0.82\left(3 \mathrm{H}, \mathrm{CH}_{3}-\right), 1.12-1.68\left(14 \mathrm{H}, \mathrm{CH}_{3}-\mathrm{CH}-\mathrm{Si}+-\mathrm{CH}_{2}-+\right. \\
\left.\mathrm{CH}_{3}-\right), 3.5-3.96\left(6 \mathrm{H},-\mathrm{CH}_{2}-\mathrm{O}\right)\end{array}$ \\
\hline M9 & $\begin{array}{l}0.16\left(3 \mathrm{H}, \mathrm{CH}_{3}-\mathrm{Si}\right), 0.84\left(5 \mathrm{H}, \mathrm{CH}_{3}-+-\mathrm{CH}_{2}-\mathrm{Si}\right), 1.24-1.68\left(10 \mathrm{H},-\mathrm{CH}_{2}-+\mathrm{CH}_{3}-\right) \text {, } \\
2.04\left(2 \mathrm{H},-\mathrm{CH}_{2}-\mathrm{COO}\right), 4.09\left(6 \mathrm{H},-\mathrm{CH}_{2} \mathrm{O}\right)\end{array}$ \\
\hline M10 & $\begin{array}{l}0.15\left(3 \mathrm{H}, \mathrm{CH}_{3}-\mathrm{Si}\right), 0.64-0.86\left(5 \mathrm{H}, \mathrm{CH}_{3}-\mathrm{C}+-\mathrm{CH}_{2}-\mathrm{Si}\right) \\
1.26\left(6 \mathrm{H},+\mathrm{CH}_{3}-\right), 2.05\left(1 \mathrm{H},-\mathrm{CH}_{2}-\mathrm{COO}\right), 4.09\left(7 \mathrm{H},-\mathrm{CH}_{2} \mathrm{O}+\mathrm{CH}_{3}-\mathrm{O}\right)\end{array}$ \\
\hline M11 & $\begin{array}{l}0.15\left(3 \mathrm{H}, \mathrm{CH}_{3}-\mathrm{Si}\right), 0.65-0.9\left(8 \mathrm{H},-\mathrm{CH}_{2}-\mathrm{Si}+\mathrm{CH}_{3}-\mathrm{C}+\mathrm{CH}_{3}-\right) \\
1.06-1.68\left(10 \mathrm{H}, \mathrm{CH}_{3}-+-\mathrm{CH}_{2}-\right), 2.04(1 \mathrm{H},-\mathrm{CH}-\mathrm{COO}), 3.8-4.06\left(6 \mathrm{H},-\mathrm{CH}_{2} \mathrm{O}\right)\end{array}$ \\
\hline M12 & $\begin{array}{l}0.16\left(3 \mathrm{H}, \mathrm{CH}_{3}-\mathrm{Si}\right), 0.74\left(2 \mathrm{H},-\mathrm{CH}_{2}-\mathrm{Si}\right), 1.2\left(6 \mathrm{H}, \mathrm{CH}_{3}-\right) \\
1.64-2.02\left(5 \mathrm{H},-\mathrm{CH}_{2}-+\mathrm{CH}_{3}-\mathrm{C}=\right), 3.6-4.04\left(6 \mathrm{H},-\mathrm{CH}_{2}-\mathrm{O}\right), 5.1-6.24\left(2 \mathrm{H}, \mathrm{H}_{2} \mathrm{C}=\right)\end{array}$ \\
\hline
\end{tabular}

to $200 \mathrm{~min}$, and total yield gradually decreased to $91 \%$, and this yield decreased to $83 \%$ at the 19 th cycle. After 19th cycle, reaction time is obviously increased and the total yield is significantly decreased with increase of the run number.

\section{CONCLUSIONS}

Thiolmethylated poly(styrene-divinyl benzene) bound platinum complex (xPSt-SH-Pt) may be used 
to catalyze hydrosilylation of various olefins with DCMS or DEMS. This complex has high activity for the hydrosilylation of styrene and alkyl acrylates, but no any activity for the hydrosilylation of olefins containing two substituents on $\mathrm{C}=\mathrm{C}$ bond. Catalytic activity, selectivity and structure of addition product are determined by electronic and steric effects of the reactants. Good reusability in styrene addition by DCMS was observed. In comparison with homogeneous chloroplatinic acid and reported polymer bound catalysts, different catalytic behavior of the xPSt-SH-Pt complex was observed.

\section{REFERENCES}

1. J. L. Speier, F. P. Mackay, O. W. Steward, and P. G. Campbell, J. Am. Chem. Soc., 79, 974 (1957).

2. J. W. Ryan and J. L. Speier, J. Org. Chem., 24, 2052 (1959).

3. E. Bennet, J. Organomet. Chem., 28, 137 (1971).

4. H. Watanabe, M. Asami, and Y. Nagai, J. Organomet. Chem., 195, 363 (1980).

5. C. W. Macosko and J. C. Saam, Polym. Prepr., (Am. Chem. Soc., Div. Polym. Chem.), 26(2), 48 (1985).

6. M. Gerard and M. Theo, Patent Co-operation Treaty International Application, WO 9525735 A1 (Sep. 28, 1995).

7. J. M. Lin, Q. Z. Yang, and C. Y. Kan, J. Shandong Univ. Nat. Sci. Ed, 34, 456 (1999).

8. K. Kishi, T. Ishimaru, M. Ozono, I. Tomita, and T. Endo, J. Polym. Sci., Part A: Polym. Chem., 38, 35 (2000).

9. K. Kishi, T. Ishimaru, M. Ozono, I. Tomita, and T. Endo, Polym. J., 32, 294 (2000).

10. M. Capka, P. Sovabodo, M. Cerny, and J. Hetfleje, Tetrahedron. Lett., 50, 4787 (1971).

11. K. G. Allum, R. D. Hancock, I. V. Howell, R. C. Pitkethly, and P. J. Robinson, J. Organomet. Chem., 87, 203 (1975).

12. M. Mejstrikova, M. Kraus, and R. Rericha, Collect. Czech. Chem. Commun., 39, 135 (1974).

13. M. Capka, P. Svoboda, M. Kraus, and J. Hetflejs, Chem. Ind. (London), 650 (1972).

14. Z. M. Michalska, M. Capka, and J. Stoch, J. Mol. Catal., 3, $125(1977 / 78)$.

15. C. Y. Hu, X. M. Han, Y. Y. Jiang, and T. Y. Shi, J. Macromol. Sci-Chem., A26, 349 (1989).

16. Y. Y. Chen, X. R. Lu, and G. Q. Fang, Chinese J. Appl. Chem., 9, 26 (1992).

17. K. Matsumura and S. Ichinohe, Japanese Patent H08-127584 A2 (May 21, 1996).

18. J. Yao, Y. Y. Chen, and B. S. Tian, J. Organomet. Chem., 534, 51 (1997).

19. L. M. Bronstein, Y. A. Kabachii, M. V. Seregina, O. A. Platonova, D. M. Chernyshov, and P. M. Valetsky, Polym. Bull., 40, 173 (1998).

20. L. Z. Wang and Y. Y. Jiang, J. Organomet. Chem., 251, 39 (1983).

21. Y. F. Li, Polym. Bull. (Chinese), 3, 12 (1989).

22. C. Y. Kan, Q. Yuan, Y. Yang, and X. Z. Kong, Chem. J. Chin. Univ., 16, 1806 (1995).

23. C. Y. Kan, Q. Yuan, A. G. Luo, and X. Z. Kong, Polym. Adv. Technol., 7, 76 (1996).

24. K. J. Olgierd, Inorg. Chem., 2, 825 (1963).

25. C. Y. Hu, D. Y. Zhao, and Y. Y. Jiang, Catal. J. (Chinese), 10, 213 (1989)

26. L. H. Sommer, A. W. James, and H. B. Garrett, J. Am. Chem. Soc., 79, 2764 (1957).

27. T. Okawa and S. Yamada, European Patent 0693492 A1 (Jan. 24, 1996).

28. Z. D. Du, J. H. Chen, X. L. Bei, and C. G. Zhu, "Organosilicon Chemistry (Chinese)", High Educational Press, Beijing, 1990, p 184. 